\title{
Current Trends, Challenges and Prospects of Student Mobility in the African Higher Education Landscape
}

\author{
Emnet Tadesse Woldegiorgis ${ }^{1} \&$ Martin Doevenspeck ${ }^{2}$ \\ ${ }^{1}$ Bayreuth International Graduate School of African Studies (BIGSAS), Germany \\ ${ }^{2}$ Department of Geography/Bayreuth International Graduate School of African Studies (BIGSAS), Germany \\ Correspondence: Emnet Tadesse Woldegiorgis, University of Bayreuth, Bayreuth, Germany. Tel: 49-1-798-519-662. \\ E-mail: Email: emnetadesse@yahoo.com
}

Received: February 23, 2015

Accepted: March 18, 2015

Online Published: March 20, 2015

doi:10.5430/ijhe.v4n2p105

URL: http://dx.doi.org/10.5430/ijhe.v4n2p105

\begin{abstract}
Since the 1990s, the development in the international dimension of higher education including student/scholar mobility, regional and international research networks and initiatives have brought new opportunities for African higher education to be incorporated in the global knowledge production and circulation processes. One of the instruments of internationalization process that facilitates international knowledge flows in the knowledge society is academic mobility. This research will touch upon the major issues related to student mobility in Africa since the 1990s addressing pressing issues like; what is the current trend of both intra and inter African student and staff mobility in higher education in the region? How do the continental initiatives already in place to promote student and academic mobility work? What are the challenges and prospects of academic mobility in Africa? Recent developments in the area have also been described through quantitative and qualitative data generated from primary and secondary sources.
\end{abstract}

Keywords: Higher education, Internationalization, Student Mobility, Knowledge circulation

\section{Introduction}

The growing trend of international academic and student mobility is associated with the growing phenomenon of globalization and internationalization processes. Globalization has transformed the trend of interdependence of nations and mobility of people to a higher level with the expansion of Information Communication Technology (ICT), the increased flow of people, ideas, capital, values, goods and services across borders. As globalization shapes higher education policy discourses in many regions and promote interdependence, it can be argued that higher education institutions should also maintain their competitiveness in the process of interdependence. Competitiveness can be understood as the capacity of higher education institutions to create, develop, consume and disseminate knowledge in the global environment. Exchange of knowledge through collaborative research activities, attracting international talents and promoting student mobility is considered to be one of the mechanisms to constantly be in touch with the global knowledge flow. The policy responses of higher education institutions, governments and regional organizations towards the forces of globalization are understood as internationalization process. As it is defined by Knight (2008), internationalization is "...integrating an international [and] global dimension into the purpose, functions or delivery of higher education." $(2008$, p. 2). Internationalization is thus a coping mechanism to the forces of globalization as stated by Altbach (2004) "...internationalisation includes specific policies and programmes undertaken by governments, academic systems and institutions and even individual departments or institutions to cope with or exploit globalisation" (Altbach, 2004, p. 6).

African higher education institutions in general have a marginalized position in knowledge production and dissemination processes. Since 1980s, African higher education institutions have faced more serious challenges in many aspects of their development than any other region. The issue of brain drain, deteriorating quality and relevance of programs, huge enrollment pressure with limited infrastructure, poor research outputs and difficulty of coping up with global changes have been the main challenges of the sector since then. Moreover, for many African countries, their sheer size, fragile socio-economic state and poor educational infrastructure make their higher education sectors less competitive. As a result, African higher education institutions found themselves in a marginalized position in the process of knowledge production and dissemination. 
Since the beginning of the 1990s however, not only the significance of higher education has been recognized in Africa but has also been brought to the priority line by governments, international financial institutions and donors. The trend in international partnership in higher education has also been growing for research, joint academic programs and development since the 1990s. This particular paper focuses mainly on academic and student mobility among African higher education institutions and beyond. Here, it should be clear that student mobility is understood as the movement of students to other countries to take either short or long term trainings in higher education. Conceptualizing student mobility in higher education has been challenging as students movement across national borders has sometimes been confused with other concepts like migration and brain drain. Student mobility could be for a short period of time as in 'exchange programs' or it could be for the whole program as in 'study abroad'. If students however decide to stay and work after graduation, then it can be termed as 'working abroad' or 'skill migration' (Altbach, 2004; Fahey, 1987). Thus, international student mobility can be explained incorporating those students that cross borders and stay in another country to take either short or long term trainings in higher education and it could be within a region -intra-regional or among countries across different regions inter-regional.

Thus, this article will address the general trend of African student mobility and its challenges. The intra and inter regional student mobility in Africa and their challenges are discussed separately. Recent trends and regional policy frameworks designed to facilitate African student mobility are also discussed in brief. The paper finally concludes by indicating the prospects and current challenges of African student mobility.

\section{Trends in Student Mobility in Africa}

The efforts of countries and their institutions to attract international students to come and study in their universities is becoming one of the major marketing areas of internationalization. Sending students in foreign intuitions to study in various higher education fields has also been taken as a strategy in many higher education institutions for a number of reasons. Exchange of good practices, information and knowledge; capacity building in research and development; attracting talented minds from all over the world; generating income from international students through tuition fees and promoting cultural integration are some of the rationales for promoting international student mobility. As globalization shapes higher education institutions in line with market elements making education a tradable commodity, competitiveness to attract more students and research funding has become one of the strategies of internationalization. Students are now considered as consumers who perceive higher education intuitions as sellers or vendors. On the other hand, higher education institutions look at students as paychecks. At the same time, higher education institutions also need to be competitive in knowledge production and dissemination processes. Thus, attracting best minds and most talented students' from all corners of the world has been one of the objectives of promoting international students mobility. Moreover, higher education sectors in some regions may not be in a position to meet all demands of local students because of the lack of adequate infrastructure, the presence of limited disciplines and post graduate programs. In such context internationalization could be adopted as a strategy to train local students in the international environment so that they may gain knowledge that may not necessarily be available in local institutions. This section explains inter and intra regional trends of student mobility in Africa.

\section{Inter-regional African Students Mobility Trends}

Mobility of African students, in all senses, is not a recent phenomenon in the African higher education landscape. With the introduction of European higher education systems in Africa during colonial times, mobility of African students to European universities for higher education training started to become common. In British and French colonies in particular, sending few African students to their respective home institutions for higher education training was taken as a strategy for colonial administration (Woldegiorgis \& Doevenspeck, 2013). Since the very purpose of higher education during colonial times was to create elites that could assist colonial administration, sending few African students to metropolitan universities in Europe was considered as cost effective compared to expanding higher education institutions in Africa (Woldegiorgis \& Doevenspeck, 2013). That was one of the European colonialist's reasons for having few higher education institutions in their colonies in Africa. The British for example established the university of East Africa to serve Tanzania, Kenya and Uganda, a combined population of 23 million with only 99 African graduates in 1963 (Altbach, 2004). In the same way, there were also only two higher education institutions in Portuguese speaking Africa (University of Luanda and the University of Lourenco) in the 1960s that were mainly established for Portuguese settlers. Out of a student population of 540 at the University of Lourenco in Marques, for instance, only one student was a Mozambican African in 1966 (Woldegiorgis \& Doevenspeck, 2013). These historical legacies however continued even after independence in most of Africa.

Since there were few higher education institutions in the continent at the time of independence, the newly independent African governments used to send students abroad for higher education trainings. Though it was very 
limited at the early years, African students gradually started to move to various destinations in Europe and America in the 1980s. According to estimation by UNESCO, there were 183,000 African higher education students studying abroad in the 1980s representing $20 \%$ of the total foreign student population in the world (Fahey, 1987). At the early stage of independence through the 1990s, the major factor for African students to travel outside of Africa for higher education training were mainly (i) the presence of few higher education institutions in the region compared to the growing number of students (ii) the presence of few post-graduate programs as most colonial universities used to focus only on undergraduate programs; (iii) availability of scholarships from the host countries and (iv) the possibility of leading a better life in a much developed social setting in Europe and America. Even though there has been expansion in the number of higher education institutions in Africa, some of the above factors however persisted in the post 1990 period. For instance, despite very substantial increases in enrollment over the past four decades, with an average annual growth rate of $8.4 \%$, compared to $4.3 \%$ for the world as a whole, African higher education institutions have still been facing the greatest challenges of accommodating the growing demand of higher education provision. At the current rate of expansion, it is projected that by 2015 Africa will have twice as many higher education students as in 2006 (i.e. about 18.6 million enrolments in 2015) which means more students are likely to study abroad if African higher education institutions keep growing with the current pace (UNESCO, 2009).

According to the UNESCO Institute for Statistics (UIS), the trend of African students going out to other regions for higher education studies has been rising since the 1990s. According to recent statistics, six percent of African students are studying abroad in 2010 "There were 380,376 African students on the move in 2010, representing about a tenth of all international students worldwide and 6\% of all African students" (Marshall, 2013). This number is even projected to reach 8 million by 2020 . Apart from the above reasons mentioned for the early years of international student mobility from Africa, additional factors including the availability of diverse number of programs, access to quality education, more career opportunities associated to foreign degrees, availability of scholarships and on study job opportunities, and flexible entry requirements have facilitated the rise in the number of African students going abroad for higher education. Here, the emergence of the wealthy class who can afford to pay tuitions in foreign universities in some parts of Africa could not also be underestimated contributing to the growing number of African students in foreign universities.

In terms of destination, most African students travel to France, UK, USA, Germany, Malaysia, Italy and Australia. According to the 2010 census, the percentage of African students who traveled to the above countries was stated as France $(29.2 \%)$ the UK (10\%), USA (9.7\%), Germany (4\%), Malaysia (3.9\%), Italy, and Australia(ICEF Monitor, 2013). On the other hand, the top 6 African countries that send most students abroad in the same year were Morocco 42,800 (11.3\%), Nigeria 38,851 (10.2\%), Algeria 22,465 (5.9\%), Zimbabwe 19,658 (5.2\%), Cameroon 19, 506 (5.3\%) and Tunisia 19,506 (5.1\%) (Marshall, 2013). France has been the most favored destination for African students for the past 20 years. Most of the students studying in France have however been from Francophone Africa as only 2.6\% of Africans studying in France are from English-speaking African countries. This trend is partly associated to the education policy of France during colonial times which has persisted even after independence. As a result of their assimilation policy, the French did not establish as many higher education institutions as the British in their colonies instead they preferred to send few Africans to study in France. That trend has also persisted after independence as France continued to give more scholarships to African students to study in France than to provide development support for universities in Africa. This has been demonstrated by the fact that more than half of the scholarship grants provided by the French government has been given to students from their ex-colonies since the 1990s(Marshall, 2013). There are now less higher education institutions in Francophone than Anglophone Africa and the trend of sending student to former colonies has still persisted in former French colonies of African countries. For instance, African students in general constituted $43 \%$ foreign students in France in 2011 and only 3\% of them were from non-francophone countries. But recently the number of students from Francophone African countries studying in English speaking countries is also rising. South Africa particularly is becoming one of the destinations for many African students including those from Francophone countries (Chien \& Kot, 2012). 


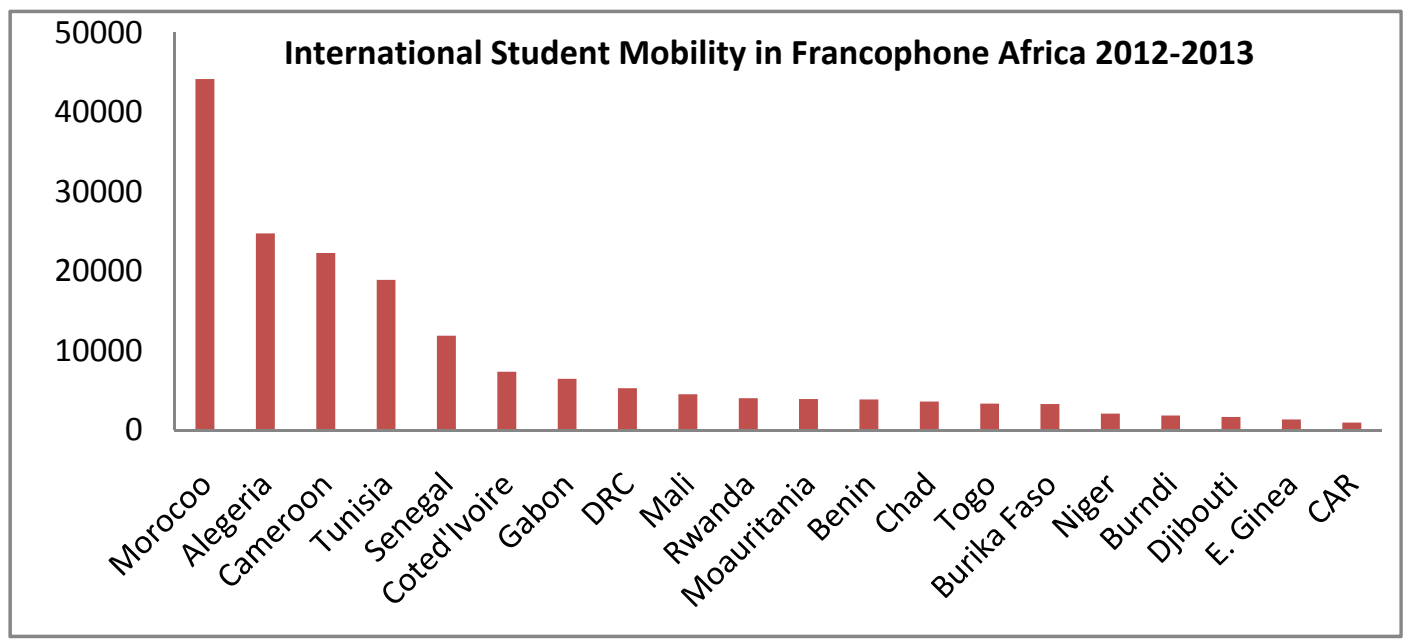

Source: Compiled by Author from UNESCO Institute for Statistics (UIS) and national MOE Statistics (2014)

Here it is clearly observed that, international student mobility in Africa follows colonial language ties as Francophone, Anglophone and Lusophone Africa. According to the 2012-2013 statistics, for example, France was the top destination for students from Francophone Africa except for countries like Chad, Equatorial Guinea, DRC and Rwanda.

According to data from UNESCO, countries like Zimbabwe, Nigeria, South Africa, Kenya, Egypt, Botswana, Ethiopia and Ghana have also been the major senders of international students from Anglophone Africa since the 1990s(UNESCO Institute for Statistics, 2007). The 2012-2013 statistics also confirmed the continuation of that trend in Anglophone Africa with Nigeria $(49,531)$, Zimbabwe $(27,993)$, Kenya $(13,575)$ and Ghana $(9,607)$ being the top four senders of international students (see table below)

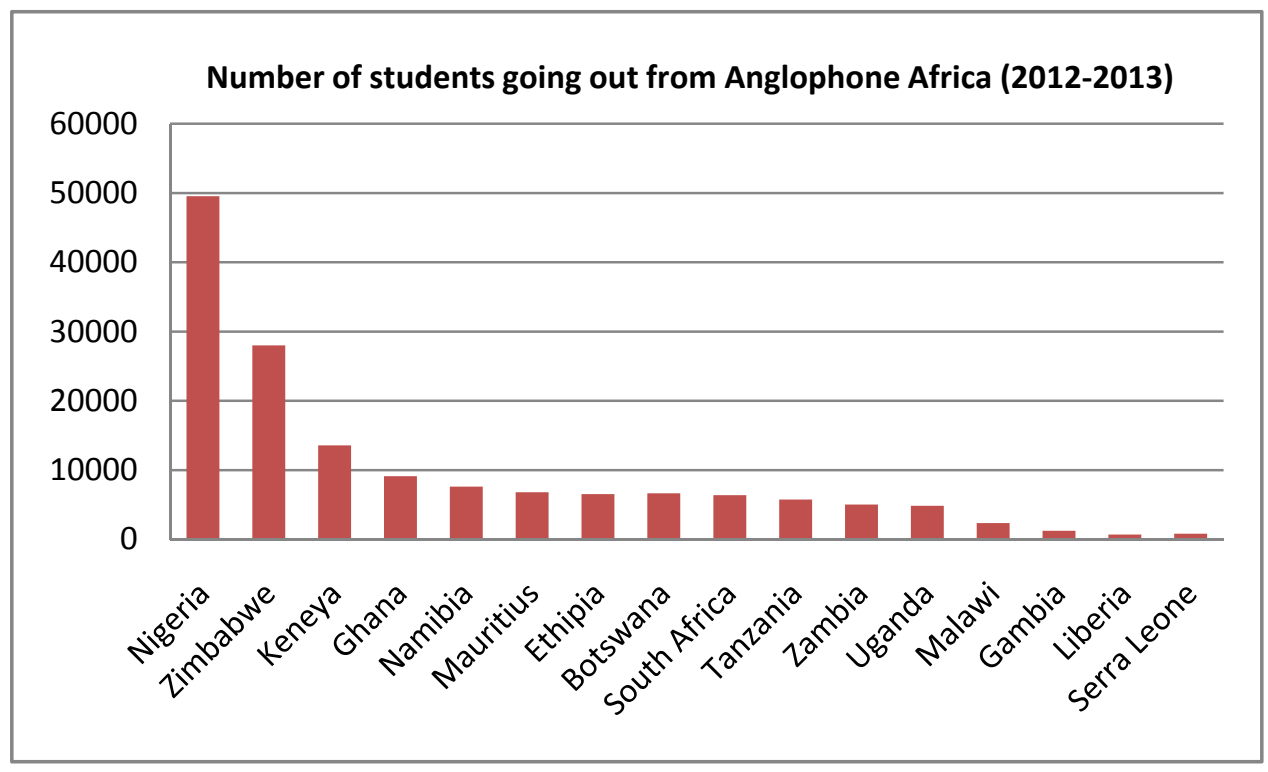

Source: Compiled by Author from UNESCO Institute for Statistics (UIS) and national MOE Statistics (2014)

In the case of international students from Anglophone countries, the top destination varies among USA, UK and South Africa.

In addition to the major destination explained above, countries like Italy, Australia, Sweden, Norway, Finland, China, India, Japan, are now attracting African students as well. The introduction of 'full-cost' tuition fees in some 
Scandinavian countries like Sweden and Denmark however, has dramatically decreased the number of not only African students but also other international students travelling to these destinations since 2011. According to the "Higher Education in Sweden 2012 status report" for example, the number of international students from non-EU countries travelling to Sweden has shown a drop of 79\% in the 2011-12 academic year alone (Swedish Higher Education Authority, 2012). Sweden's fees for students from outside Europe has followed a similar move by Denmark in 2006, when non-EU-EEA student numbers fell from 1,528 in 2005 to 995 in 2006 - a 33\% decline. The number of students travelling to new destinations in the East has also been increasing since the 1990s. There were few African students for example, studying in China until the 1990s. As stated by UNESCO (2011:1) "Throughout the 1950s, there were only 24 African students studying in China from Egypt, Cameroon, Kenya, Uganda, and Malawi, and 3 Chinese teachers teaching in Africa." This number however kept rising in the 1980s reaching 2,245 African students striding in Chinese universities from 43 different African countries (UNESCO, 2011). According to recent statistics, there are about 15,500 African students studying in China by 2012 (Changsong, 2013).

International student mobility in the Portuguese speaking (Lusophone) Africa has also follow the same trend since Portugal has been the top designation for most of the students form Lusophone Africa.

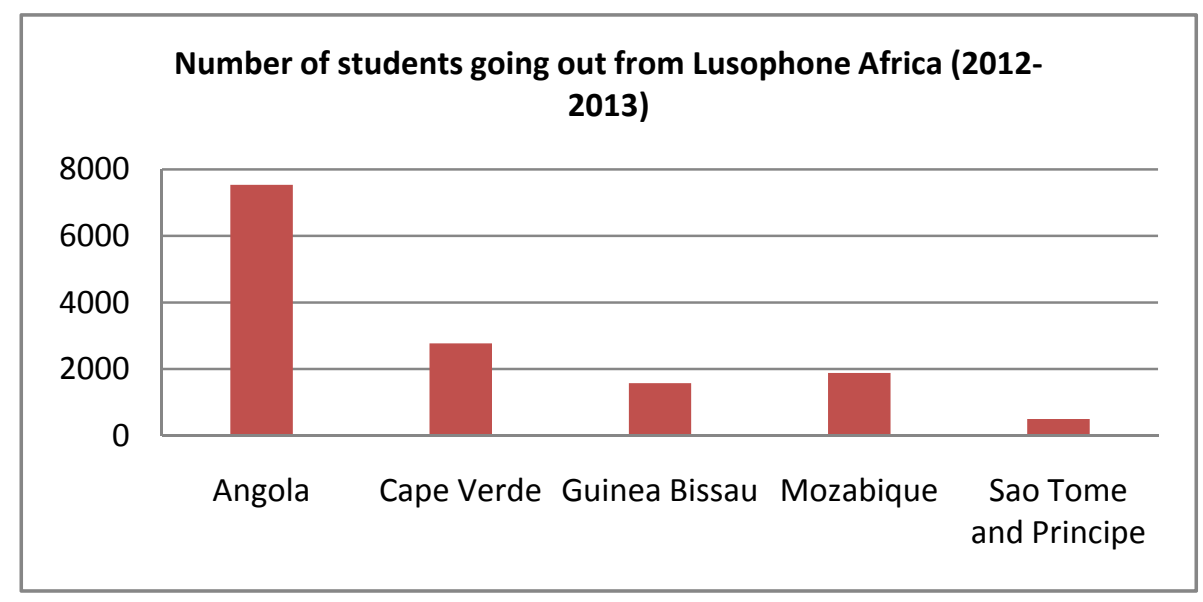

Source: Compiled by Author from UNESCO Institute for Statistics (UIS) and national MOE Statistics (2014)

If we look at the mobility trend of students from Lusophone Africa countries, the top destination in all of them except Guinea-Bissau was Portugal in 2012 - 2013.

Generally, even though lack of comprehensive documentations on the mobility of African students makes it difficult to specifically point out the exact number of African students going out of the continents for higher education studies, available statistics indicate that African students constitute a significant share of the global student mobility.

\subsection{Challenges of inter-regional Student mobility}

International student mobility however poses both opportunities and challenges. International student mobility could be an instrument of internationalization that facilitates the participation of national institutions in international knowledge flows. In this regard, mobility and academic exchange are believed to improve teaching and administrative practices of higher education institutions through the sharing of experiences and success stories in different contexts. Student mobility also has economic advantages for host countries in generating revenues. For instance, international students have contributed as much as US\$8.12 billion per year to the Australian economy (Australian Government, 2011). In New Zealand, higher education service has been the country's fifth largest service export since 2005 and education services have generated as much as US\$1.46 billion per year in foreign exchange, placing it firmly amongst New Zealand's leading industries(Verbik \& Lasanowski, 2007). In this regard, developed nations are the beneficiaries of international student mobility as more than $90 \%$ of international students have enrolled in institutions in OECD countries. Six countries - the U.S., the UK, Germany, France, Australia, and Japan have been dominating the flow of international students hosting $67 \%$ of the world's international students (Verbik \& Lasanowski, 2007).

At the same time however, international student mobility could also facilitate and be an instrument of brain drain for sending nations particularly from developing countries. The impact of Brain Drain cannot be underestimated if 
students keep on deciding to stay in the host countries after graduation. Different studies confirmed that a significant number of African students do not return back to Africa after finishing their studies. Damtew Tefera (2000) has for example documented that between 1991 and 2000 about $50 \%$ of Ethiopians who went abroad for training did not return after completing their studies (Teferra, 2000). He further indicated that Africa has lost one third of its human capital since 1990. Barka (2000) citing International Organization for Migration (IOM), has also confirmed that Ethiopia has lost about $74.6 \%$ of its human capital from various institutions between 1980 and1991 (Barka, 2000). There are currently over 300,000 highly qualified Africans in the Diaspora, 30,000 of which have PhDs. Here even though there are many other factors that contributed to the increasing trends of brain drain from Africa, inter-Africa student mobility however, cannot be disregarded as a factor. Thus, even though international student mobility could be an instrument to attract best minds from all over the world for host countries, it could also be a devastating cause of brain drain for sender nations.

In the long run, as host countries from the developed world receive more international students and attract global talents, 'centre-periphery' relationships could also emerge in the process of knowledge production and dissemination between developed and developing nations. As higher education institutions from the developed world (the center) attract more talented students and manage to retain them contributing to the knowledge production and distribution in the host countries, institutions from developing countries, (the periphery) would assume a dependent position relying on technologies, knowledge, goods and services produced by the centre. Countries with highly advanced infrastructure, attractive salaries, and advanced research facilities have strong competitive advantage to attract talented international students who bring along with them international experiences and contribute to the development of knowledge economy in the host countries. African universities in this regard are the most vulnerable institutions because of their weak financial and infrastructural settings that contribute to their marginalization in knowledge production and dissemination processes. Thus, unless African higher education institutions develop their capacity to attract and retain both African and international students, international student mobility might lead to overwhelming impact of brain drain in the continent. As Dr. Lalla Ben Barka Deputy Executive Secretary ECA stated it, "African governments have a great responsibility to ensure that brains remain in the continent; otherwise, in 25 years' time, Africa will be empty of brains" (Chawawa, 2013)

\section{Intra-Regional African Students Mobility Trends}

Apart from the South-North (inter-regional) student mobility however there is also a growing trend in the south-south (intra-regional) student mobility since the 1990s. Various factors have contributed to the growing trend of intra-African student mobility since the 1990s. Among others, the relative economic developments and political stability in some African countries since the mid 1990s, the collapse of Apartheid in South Africa and the growing higher education sector since 1994, the progressive economic integration among East African countries and the rapid expansion of higher education in Northern African countries are some of them. The intra-Africa mobility of students and staff has more than doubled in the past decade, with the major poles being South Africa and Angola (from Southern Africa), Kenya and Uganda (from East Africa), Tunisia and Morocco (from North Africa) and Senegal and Ghana (from West Africa)(ICEF Monitor, 2013).

For instance Morocco has been one of the top destinations for students from other North African countries hosting 6,996 African students in 2010 particularly from Tunisia and Algeria (Marshall, 2013). The availability of scholarship, the presence of more international branch campuses of foreign universities, low cost of tuition in the fields of medicine, engineering and administration have been mentioned among the major reasons for Morocco to become the most favored destination for North African Students (Marshall, 2013). In the same way, South Africa has also become a major destination for African students largely from SADC region such as Zimbabwe, Namibia, Botswana and Lesotho since 1994. In 2009, for example, South Africa has been rated among the top 10 destinations for foreign students to pursue a university education away from home (Note 1). According to the Global Education Digest 2009 study (cited in Sunday Times July 26, 2009), 8\% of students in South African universities were international students mainly for SADC region. In 2010 for instance, of all foreign students in South African universities, $72 \%$ came from SADC region. Generally, since the fall of the Apartheid regime, the number of international students in South Africa has more than quadrupled from around 12,500 in 1994 to nearly 53,000 in 2005. Large number of international students also enrolled in distance programs in South Africa. Distance Education, for example, has constituted 40\% of education provision in South Africa between 2003 and 2006 (Ibid).

Intra-African student mobility among Portuguese speaking African countries has also been emerging after the conclusion of the long civil wars in Angola. Though the higher education space in Lusophone Africa is not as big as Francophone or Anglophone countries, Angola has been playing a major role as a main destination for international 
students from Portuguese speaking African countries. Even though Angola has a relatively young higher education experience because of the colonial policy of the Portuguese and the consequent civil wars in post independence era, it has exhibited fast improvement in higher education provision and has recently become one of the destinations for international students from Africa. In 2010, Angola hosted 6,530 foreign students, mostly from its Portuguese-speaking countries of Cape Verde, Mozambique, and São Tomé and Príncipe. Students from the Democratic Republic of Congo and Guinea-Bissau are also choosing Angola for their higher education trainings(Marshall, 2013). Among other things, the fast growing economy of Angola, growing labor market for Portuguese speaking Africans, scholarship opportunities and relative peace contributed to the growing number of international students in Angola.

Student exchange in East African countries basically goes back to colonial times where Makerere University of Uganda used to be the only higher education institution in the region serving students from Kenya, Tanzania and beyond. Students have been travelling since then to Uganda for higher education training from various parts of Africa. The quality of education at Makerere University used to be comparable to universities in the U.K. and this has given the university a reputation of being the 'Harvard of Africa' (Domatob, 1996). This trend has continued for a long time making Uganda the main destination for international students from East Africa. According to official reports from the Ministry of Higher Education in Uganda, for instance, there were about 16,000 international students at Uganda's universities in 2010 constituting almost $10 \%$ of the total higher education students in the country(Herrmann, 2012). It is not only Makerere University but also other universities in Uganda that are currently hosting international students; for example, Kampala International University (KIU) hosted 6,715 students, Islamic University in Uganda hosted 767, Makerere University Business School hosted 671 in 2010 (Ibid). The majority of international students (70\%) are from Kenya while the rest come from Tanzania, Democratic Republic of Congo, Burundi, Rwanda, Sudan, Somalia and Congo. The relatively low cost of living and tuition fees in Uganda, better quality higher education, easy visa regulations and geographic proximity contributed to the large number of foreign student enrollment in Ugandan universities.

\subsection{Challenges of intra-regional Student mobility}

Even though the trend of intra-regional mobility in Africa showed improvement since the 1990s, it has also been facing various challenges. Student mobility is a function of various elements including political stability, availability of quality higher education infrastructure, availability of credit transfer systems and instrument of recognition of studies, flexible entry mechanisms, conducive visa procedures, and harmonized or comparable higher education systems. The above enabling factors however are rarely available in most countries in Africa which is challenging the development of intra-regional student mobility in Africa. Moreover, a policy framework at institutional level is requested to facilitate internationalization of higher education in general. Most universities in Africa however do not have internationalization strategy or policy and thus it is now difficult to identify the positions of institutions when it comes to international student mobility. The general absence of institutional mechanism that supports student mobility has contributed to the poor marketing and position of African universities in the global market. Most African higher education institutions do not even have a comprehensive data on student mobility. Existing data on student mobility and staff exchange programs are inconsistent, incomplete and in most cases not collected by central agency in any standard format which makes it difficult to have meaningful comparisons for study. Although some universities are in the process of establishing international offices - in South Africa, Morocco, Ghana, Nigeria, Egypt, Uganda, Angola - to deal with international students, still the number of universities that have internationalization policy in Africa are insignificant.

Moreover, enabling factors of student mobility like the existence of Credit Accumulation and Transfer System (CATS) which facilitates the recognitions of course taken in other universities and making them comparable other has not been practiced in a comprehensive manner in the region. The CATS has been proved in many regions, including Europe, as a facilitating factor for mobility of students to enhance transparency and comparability of study programs and qualifications, and facilitate the recognition of studies (TEMPUS STUDY, 2010). Diverse higher education systems and curriculum structures across higher education institutions in the region have also contributed to the challenges of student mobility. The many different higher education systems in Africa, which are based on different national or colonial and other legacies, are not yet harmonized. Thus, credential evaluation has become a topic of increasing concern in African universities whenever they admit international students. Currently, initiatives are going on both at regional and sub-regional levels to introduce CATS in African higher education.

Apart from that, technical challenges of visa and border regulations, perpetual political unrest in some African countries also contributes to the slow rate of mobility among African countries. In most cases, African students feel 
more secured and safe when they travel to Europe and America than to neighboring countries. Thus the mobility of students is linked to the diverse socio-economic and political realities of Africa. Peace and security, economic growth and development, comparable and affordable infrastructures are important to promote mobility of African students across African institutions. To address the above challenges, the collaboration of the AUC and sub-regional organizations is also crucial in facilitating the smooth movement of the whole process.

\section{Current Regional Initiatives}

Even though both intra and inter African mobility of students is as old as the emergence of higher education in Africa itself, the issue of promoting student and staff mobility at policy level in Africa mainly expanded after the adoption of the Accra Declaration in 2004. The Accra Declaration was an outcome of a conference of high profile experts and policy makers (Note 2) of higher education which was organized by the Association of African Universities (AAU) in partnership with UNESCO and the South African Council on Higher Education. On the meeting, the participants clearly affirmed that African higher education is less internationalized and characterized by poor academic mobility among African institutions. Thus, on the final Declaration which was unanimously adopted after the conference, the participant avowed their commitments to promote student mobility.

...We therefore re-affirm our commitment to reducing obstacles to international co-operation in respect of knowledge creation, exchange and application, to the enhancement of access to higher education and to increasing academic mobility within Africa itself (Accra Declaration, 2004, p. 4)

Within the framework of the Accra Declaration, one of the regional mobility schemes developed by the African Union (AU) is the Mwalimu Nyerere mobility scheme. The Mwalimu Nyerere mobility program is an intra-African mobility program which was crafted in 2007 and named after one of the icons of pan-Africanism and the first leader of Tanzania, Julius Nyerere. The Mwalimu Nyerere mobility scheme was initiated "to develop and retain high quality human resource for Africa's development, while enhancing intra-Africa institutional networking, academic mobility and quality" (European Commission, 2013). It was designed to enable African students to undertake degree programs (Bachelors', Masters' and $\mathrm{PhD}$ ) in leading African universities, in the areas of science and technology, with a binding agreement that the beneficiaries will work in Africa for two to five years after graduation. As a mobility program, it was intended to promote the notion of intra-regional student mobility among African higher education institutions. Regional student mobility programs in general are however very expensive and need strong organizational frameworks. The European student mobility scheme or Erasmus program, for example, costs about 230 million Euros every four years in order to facilitate the mobility of about 6,000 students within European universities (EACEA, 2014). The AU mobility program in this regard is underfunded with about 45 million Euros; as a result it has only managed to facilitate mobility for few African students. In 2008 for example, only 19 African students participated in the Nyerere mobility program and two years later in 2010 the number was again only 24 (African Union, 2014). The major reason for the limited impact of the program in terms of promoting student mobility has been the lack of financial resource, according to the AU education experts.

As a way out of these challenges, the AU crafted a two edged strategy of minimizing cost and mobilizing resources. One of the decisions made to minimize the cost of mobility for was the waving of tuition fees for the participants of the Nyerere mobility program in their host university. Accordingly, the AU passed a decision demanding member states to consider the Nyerere scholarship award holders as home students on the Fourth Ordinary Session of the Conference of AU's Ministers of Education (COMEDAF IV) which was held in Mombasa, Kenya from 23-26 November 2009.

Call on Member States to consider treating Mwalimu Nyerere African Union Scholarship award holders as home students for fee determination, and urged the AUC to finalize the planned preparations needed to ensure the timely scaling up of the programme (AU/MIN/EDUC/RPT(IV), 2009, p. 7)

Harmonizing fee structures at continental level was also taken as a long term policy direction to promote student mobility but as a short term solution the AU called upon member states to wave tuition fees for Mwalimu Nyerere Scholarship award holders in order to ease the financial burden on the program and provide more scholarships for students. To address the financial and technical challenges of the program, the AU has also decided to call up on the European Commission to provide support for the Nyerere program under the Africa-EU partnership scheme. The issue of including the Nyerere program in the Africa-EU partnership scheme was discussed on the $3^{\text {rd }}$ Africa-EU Summit under the theme "Nyerere / Supporting Academic Mobility and Revitalization of Higher Education in Africa" which took place in Cape Town, South Africa 23-24 November 2010. On the conference, the EU pledged to support and fund the Mwalimu Nyerere African Scholarship Scheme to boost mobility of students and staff in higher 
education. Since then, the Nyerere scholarship program has been funded through the European Development Fund (EDF) and technically supported by the European Commission. The EDF, for instance, provided US $\$ 46.5$ million in 2010 and an additional $€ 30$ million between 2011 and 2013(European Commission, 2013).

The involvement of the EU in the Mwalimu Nyerere programme has further expanded the objectives of the program now including mobility of African students beyond Africa within the framework of the Africa-EU partnership. The Africa-EU partnership has different thematic areas one of one of which "migration, mobility and employment", incorporates higher education partnership. Thus, the EU has developed a partnership scheme called the Intra-ACP University Mobility Program which is an academic mobility scheme that promotes cooperation between higher education institutions and supports mobility in Africa, the Caribbean and the Pacific (ACP) regions. As it is clearly stated on the European Commission Education, Audiovisual and Culture Executive Agency's (EACEA) document "This programme builds on the African Union's Mwalimu Nyerere programme for Africa, granting additional funding, and setting up a similar scheme for the Caribbean and Pacific regions. It is funded through the European Development Fund (EDF)" (EACEA, 2014). The program was designed as a five year project (2010-2014) signed between EACEA and AUC with an overall budget of EUR 45 million and an annual budget of 9 million. The program has already been implemented through three calls published in 2010, 2011 and 2012 respectively and over the five consecutive rounds of selection. Accordingly, since 2010, about 250 postgraduate students have participated in the program (African Union, 2014). But still, the Mwalimu Nyerere mobility scheme only managed to facilitate mobility for an insignificant number of students and the project needs to be revisited to have a wider impact. Moreover, sustainability of the Nyerere mobility program itself is under question since it is financially dependent on European Union. Even though it has secured about $€ 45$ million from the EU for five years (2011-2015), there is no viable financial plan for the years to come as the project is already at the concluding stage.

The other important regional higher education mobility program is the Pan-African university network (PAU). The Pan-African university network was initiated by the AU in 2007 to establish post-graduate programs, mainly in science and technology, by coordinating up to 55 universities from all regions of Africa. The objective is to train and retain best minds in Africa in science and technology. This was part of the initiative to promote centers of excellence in Africa which was conceived since the adoption of the Plan of Action for the Second Decade of Education for Africa and the Consolidation the Plan of Action for Science and Technology 2006-2011. The COMEDAF repeatedly underscores the marginal role of African higher education institutions in science and technology in global knowledge production. This point has also been supported by the fact that on average, Africa has 35 scientists and engineers per million inhabitants, compared to 168 in the case of Brazil, 2,457 in the case of Europe, and 4,103 in the case of the United States (AfDB, 2013). In the same way, recent research indicates that even though Africa accounts for $13.4 \%$ of the world population, its production of knowledge is only $1 \%$ (Kigotho, 2013). Moreover, data from the UNESCO Institute for Statistics (UIS) indicates that apart from South Africa, which invests just less than $1 \%$ of GDP in research and development, most African countries invest only between zero and $0.5 \%$ of their GDP making the average investment for research and development for the region only $0.4 \%(\mathrm{AfDB}, 2013)$. The AU has thus taken the promotion of science and technology and the establishment of centers of excellence as the main way forward to address these challenges in the region. The establishment of PAU is also an extension of this plan as it was proposed by the AU in 2008 as a network of high-profile universities to train best African students or "the cream of the crop" mainly in science and technology at the Master's and PhD levels. So far the Pan-African University has recruited 193 post graduate students from all of Africa in various disciplines. Generally, even though the establishment of the Mwalimu Nyerere programmes to promote intra-African mobility is promising, its effect as an instrument of student mobility is extremely limited as the program is currently hosting less than 200 students. The program is however expected to include up to 1500 students by the end of 2015 , which seems ambitious with the current pace.

\section{Conclusion}

African student mobility both within and outside of the continent has shown a dramatic increase since the 1990s. The coming of new scholarship and mobility schemes, the growing North-South higher education partnership initiatives and the regional higher education harmonization policy initiatives that encourage student mobility has already been expanding the mobility of African students within and outside Africa. The Erasmus Mundus program which is initiated by the EU for non-EU students for example, has recently been absorbing huge number of African students to study in various European universities (EACEA, 2014). Moreover, the various higher education development cooperation schemes that African institutions are establishing have also been expanding post-graduate programs particularly at $\mathrm{PhD}$ levels promoting not only mobility but also join research endeavors. These partnership schemes have the prospects of promoting academic mobility for research, consultation and study purposes between 
African institutions and institutions from the North.

Higher education harmonization initiatives at regional level have also broadened the prospect of having smooth mobility processes within Africa. The AU higher education harmonization strategy which was adopted in 2007, for example, has taken improving the mobility, quality, transferability, comparability and relevance of academic studies in Africa as its the main objectives. Thus, the fact that mobility of students has already been the top priority of the AU higher education policy frameworks makes the prospect of having policy support for student mobility quit high. Apart from the AU initiatives, the Association of African Universities (AAU) has also been playing a crucial role in facilitating higher education partnership among African and north American intuitions. The existence of various partnership schemes and mobility strategies by themselves however, are not enough to promote student mobility in Africa. Enabling factors such as viable academic credit transfer system, regional quality assurance and accreditation framework, harmonized degree structure, harmonized tuition policy, institutionalization of internationalization processes and flexible visa procedures should also be put in place.

\section{References}

Accra Declaration. (2004). Accra Declaration on GATS and the Internationalization of Higher Education in Africa. Accra: Association of African Universiteis .

AfDB. (2013, 07 25). AfDB Approves US\$45 Million Grant for Creation of Pan African University for Science, Technology and Innovation. Retrieved 10 9, 2014, from African Development Bank: http://www.afdb.org/en/news-and-events/article/afdb-approves-us-45-million-grant-for-creation-of-pan-africanuniversity-for-science-technology-and-innovation-12155/

African Union. (2014). Report on the Mwalimu Nyerere Mobility program 2014. Addis Ababa: AAU \& AU.

Altbach, P. G. (2004). Higher education crosses borders: Can the United States remain the top destination for foreign students. Change, 36(2), 18-24. http://dx.doi.org/10.1080/00091380409604964

AU/MIN/EDUC/RPT(IV). (2009). Report of the fourth ordinary session of the conference of ministers (comedaf iv). Mombasa: african union department of human resources, science and technology.

Australian Government. (2011). Export Income to Australia from Education Services in 2010-11. Research Snapshot. Retrieved

from https://www.aei.gov.au/research/Research-Snapshots/Documents/Export\%20Income\%202010-11.pdf

Barka, B. L. (2000). Keynote Address. Regional Conference on Brain Drain and Capacity Building in Africa. Addis Ababa.

Changsong, N. (2013). China-Africa Education Cooperation Under the Framework of FOCAC. Institute of African Studies Zhejiang Normal University. Retrieved March 1, 2014, from http://www.gsid.nagoya-u.ac.jp/syamada/China-Africa\%20Education\%20Cooperation\%20Under\%20the\%20Fr amework\%20of\%20FOCAC.pdf

Chawawa, M. (2013, 06 24). Educating for employability in the global economy: the Diaspora option. Retrieved from Sunday Standard: http://www.sundaystandard.info/article.php?NewsID=17156\&GroupID=5

Chien, C. L., \& Kot, F. C. (2012). New patterns in student mobility in the Southern Africa Development Community. In B. R. Mobility. Southern African Regional Universities Association (SARUA).

Domatob, J. K. (1996). Policy issues for African universities. Issue: A Journal of Opinion, 29-35.

EACEA. (2014, August 28). Navigation path European Commission EACEA. Retrieved from About the intra-ACP academic mobility scheme: http://eacea.ec.europa.eu/intra_acp_mobility/programme/about_acp_mobility_en.php

European Commission. (2013). Thematic partnership on migration, mobility and employment action plan 2011 2013 fiches on priority initiatives. Addis ababa: AUC and EUC.

Fahey, T. (1987). Study Abroad and Development. Development Review 1987. Retrieved from http://www.trocaire.org/resources/tdr-article/study-abroad-and-development

Herrmann, K. (2012, April ). The observatory on Borderless Higher Education . Retrieved from Uganda: Moving beyond price to recruit international students: http://www.obhe.ac.uk/newsletters/borderless_report_april_2012/uganda_moving_beyond_price_recruit_intern ational_students 
ICEF Monitor. (2013, July 19). A closer look at African student mobility. Retrieved from ICEF Monitor: http://monitor.icef.com/2013/07/a-closer-look-at-african-student-mobility/

Kigotho, W. (2013, August 17). Development bank grant boosts Pan-African University. Retrieved from University World

News: http://www.universityworldnews.com/article.php?story=20130817105449256\&query=Pan-African+University

Knight. (2008). Higher education in turmoil: The changing world of internationalization. Rotterdam: Sense Publishers.

Marshall, J. (2013, July 06). International mobility of African students - Report. Retrieved from University World News: http://www.universityworldnews.com/article.php?story=20130705203103913

Swedish Higher Education Authority. (2012). Annual statistics on higher education in Sweden 2012 status report. UKA.

Retrieved

from http://english.uk-ambetet.se/statisticsfollowup/annualstatisticsonhighereducationinsweden.4.4149f55713bbd917 56380004954.htm

Teferra, D. (2000). Revisiting the Doctrine of Human Capital Mobility in the Information Age. the Regional Conference on Brain Drain and Capacity Building in Africa. Addis Ababa.

TEMPUS STUDY. (2010). State of Play of the Bologna process in the Tempus Countries of the Southern Mediterranean (2009 - 2010). Armenia: European Commission Education Audiovisual and Culture Executive Agency.

UNESCO Institute for Statistics. (2009). GLOBAL EDUCATION DIGEST 2009:Comparing Education Statistics Across the World. Montreal, Quebec: UNESCO Institute for Statistics.

Verbik, L., \& Lasanowski, V. (2007, September). International Student Mobility: Patterns and Trends. The Observatory on Borderless Higher Education.

Woldegiorgis, E. T., \& Doevenspeck, M. (2013). The Changing Role of Higher Education in Africa: A Historical Reflection. Higher Education Studies, 3(6), p35. http://dx.doi.org/10.5539/hes.v3n6p35

\section{Notes}

Note 1. Sunday Times, 26 July 2009, "Foreigners flock to South Africa Universities".

Note 2. The workshop brought 67 high profile participants together, including trade and education ministers and other senior policy-makers, Vice-Chancellors, heads of regional research and higher education organizations, representatives of national and regional regulatory agencies, sub-regional and international organizations, donors, advocacy networks, as well as consultants, journalists and other major stakeholders. 